\title{
Article \\ Serotonin Promotes Serum Albumin Interaction with the Monomeric Amyloid $\beta$ Peptide
}

\author{
Ekaterina A. Litus ${ }^{1}$, Alexey S. Kazakov ${ }^{1}$, Evgenia I. Deryusheva ${ }^{1}$, Ekaterina L. Nemashkalova ${ }^{1}$, \\ Marina P. Shevelyova ${ }^{1}$, Aliya A. Nazipova ${ }^{1}$, Maria E. Permyakova ${ }^{1}$, Elena V. Raznikova ${ }^{1}$, \\ Vladimir N. Uversky $2, *$ (D) and Sergei E. Permyakov ${ }^{1, *(\mathbb{D})}$
}

check for

updates

Citation: Litus, E.A.; Kazakov, A.S.; Deryusheva, E.I.; Nemashkalova, E.L.; Shevelyova, M.P.; Nazipova, A.A.; Permyakova, M.E.; Raznikova, E.V.; Uversky, V.N.; Permyakov, S.E. Serotonin Promotes Serum Albumin Interaction with the Monomeric Amyloid $\beta$ Peptide. Int. J. Mol. Sci. 2021, 22, 5896. https://doi.org/ $10.3390 /$ ijms 22115896

Academic Editor: Bruno Imbimbo

Received: 7 May 2021

Accepted: 28 May 2021

Published: 31 May 2021

Publisher's Note: MDPI stays neutral with regard to jurisdictional claims in published maps and institutional affiliations.

Copyright: (C) 2021 by the authors Licensee MDPI, Basel, Switzerland. This article is an open access article distributed under the terms and conditions of the Creative Commons Attribution (CC BY) license (https:// creativecommons.org/licenses/by/ $4.0 /$ )
1 Institute for Biological Instrumentation, Pushchino Scientific Center for Biological Research of the Russian Academy of Sciences, Pushchino, 142290 Moscow, Russia; ealitus@gmail.com (E.A.L.); fenixfly@yandex.ru (A.S.K.); janed1986@ya.ru (E.I.D.); elnemashkalova@gmail.com (E.L.N.); marina.shevelyova@gmail.com (M.P.S.); alija-alex@rambler.ru (A.A.N.); mperm1977@gmail.com (M.E.P.); raznikova.elena@yandex.ru (E.V.R.)

2 Department of Molecular Medicine and USF Health Byrd Alzheimer's Research Institute, Morsani College of Medicine, University of South Florida, Tampa, FL 33612, USA

* Correspondence: vuversky@usf.edu (V.N.U.); permyakov.s@gmail.com (S.E.P.); Tel.: +7-(495)-143-7741 (S.E.P.); Fax: +7-(4967)-33-0522 (S.E.P.)

Abstract: Prevention of amyloid $\beta$ peptide $(\mathrm{A} \beta)$ deposition via facilitation of $\mathrm{A} \beta$ binding to its natural depot, human serum albumin (HSA), is a promising approach to preclude Alzheimer's disease (AD) onset and progression. Previously, we demonstrated the ability of natural HSA ligands, fatty acids, to improve the affinity of this protein to monomeric A $\beta$ by a factor of 3 (BBRC, 510(2), 248-253). Using plasmon resonance spectroscopy, we show here that another HSA ligand related to AD pathogenesis, serotonin (SRO), increases the affinity of the A $\beta$ monomer to HSA by a factor of $7 / 17$ for $A \beta_{40} / A \beta_{42}$, respectively. Meanwhile, the structurally homologous SRO precursor, tryptophan (TRP), does not affect HSA's affinity to monomeric A $\beta$, despite slowdown of the association and dissociation processes. Crosslinking with glutaraldehyde and dynamic light scattering experiments reveal that, compared with the TRP-induced effects, SRO binding causes more marked changes in the quaternary structure of HSA. Furthermore, molecular docking reveals distinct structural differences between SRO/TRP complexes with HSA. The disintegration of the serotonergic system during $\mathrm{AD}$ pathogenesis may contribute to $\mathrm{A} \beta$ release from HSA in the central nervous system due to impairment of the SRO-mediated $\mathrm{A} \beta$ trapping by HSA.

Keywords: Alzheimer's disease; human serum albumin; amyloid $\beta$ peptide; serotonin; tryptophan; surface plasmon resonance; molecular docking; intrinsic disorder

\section{Introduction}

Human serum albumin (HSA; $66.5 \mathrm{kDa}$ ) is the most abundant blood and cerebrospinal fluid (CSF) protein and is vital to maintaining the osmotic pressure of blood and the transport of numerous substances, including fatty and amino acids, hormones, metal ions, and over 250 drugs (reviewed in [1,2]). HSA consists of three structurally similar $\alpha$-helical domains comprising nine fatty-acid-binding sites, four metal-binding sites, and two highaffinity drug-binding sites [2]. One of the key participants in progression of Alzheimer's disease (AD), amyloid peptide $(A \beta)$ [3], is mostly bound to HSA (ca 89\% of A $\beta$ in blood plasma [4]). This interaction effectively rescues $A \beta$ from deleterious self-aggregation and cytotoxicity [5-7]. Thereby, HSA provides ca $60 \%$ of the total amyloid inhibitory activity of plasma proteins [5]. Furthermore, the antioxidant and detoxification activities and anti-inflammatory and blood-brain barrier-supporting properties of HSA likely prevent AD progression [8].

Based on the $A \beta$-buffering role of plasma HSA, removal of plasma $A \beta$ via plasma exchange and replacement with therapeutic HSA were suggested for facilitation of $A \beta$ 
efflux from the brain of AD patients to plasma [9]. The clinical trials have shown persistent improvements in the memory and language functions of the patients [9-11]. An alternative, less invasive approach to the lowering of the free $A \beta$ level in the brain is a pharmacologically guided shift in the equilibrium between HSA and A $\beta$ towards their complex. The latter possibility was recently confirmed by arachidonic/linoleic-acid-induced enhancement of HSA affinity to $A \beta$ [12], which is in line with the observation that dietary linoleic acid reduces brain A $\beta$ deposition in AD mouse models [13]. Meanwhile, many more HSA ligands were reported to prevent HSA-induced suppression of $A \beta$ fibrillation, likely due to stimulation of $A \beta$ release from HSA: tolbutamide [5], warfarin, palmitic acid, and cholesterol [14]. Therefore, searching for HSA ligands with the opposite action is non-trivial.

Serotonin (SRO; 5-hydroxytryptamine, 5-HT) is a HSA ligand closely related to AD pathogenesis (reviewed in $[15,16]$ ). It is a phylogenetically conserved monoamine neurotransmitter that performs various physiological functions (behavior regulation, appetite suppression, regulation of energy intake, storage, and expenditure, respiratory drive, hemostasis, etc.) through interaction with multiple 5-HT receptors [17].

Numerous studies have demonstrated degeneration of the serotonin system in AD, a decline in the cortical/serum SRO level, and negative consequences of disruption in serotonergic signaling $[15,16]$. The serotonergic deficits in $\mathrm{AD}$ are more prominent compared with those for other neurotransmitters. Selective serotonin reuptake inhibitors (SSRIs) aimed at increasing the SRO bioavailability at nerve terminals are currently in clinical trials for AD [18]. In the present work, we show in vitro that SRO is the most potent activator of HSA-A $\beta$ interaction reported to date, whereas the structurally similar SRO precursor, L-tryptophan (TRP), is inactive in this sense.

\section{Results}

The HSA-A $\beta$ interaction was studied by the SPR method mainly as described earlier [12]. The recombinant human $A \beta_{40}$ or $A \beta_{42}$ sample was immobilized on the surface of the SPR sensor chip by amine coupling, followed by removal from the surface of the non-covalently bound A $\beta$ molecules by a $2 \%$ SDS water solution [12]. A fatty-acid-free HSA sample [19] $(5-60 \mu \mathrm{M})$ was used as an analyte. The measurements were carried out at $25^{\circ} \mathrm{C}$ using a physiologically relevant buffer $(20 \mathrm{mM}$ Tris- $\mathrm{HCl}, 140 \mathrm{mM} \mathrm{NaCl}, 4.9 \mathrm{mM}$ $\mathrm{KCl}, 1 \mathrm{mM} \mathrm{MgCl} 2,2.5 \mathrm{mM} \mathrm{CaCl}_{2}, \mathrm{pH}$ 7.4). The resulting SPR sensograms exhibited a concentration-dependent association-dissociation pattern and were well approximated by the one-site binding model (Figure 1). The equilibrium dissociation constants $\left(K_{D}\right)$ for intact HSA complexes with $\mathrm{A} \beta_{40}$ and $\mathrm{A} \beta_{42}$ were $0.6 \times 10^{-7} \mathrm{M}$ and $1.2 \times 10^{-7} \mathrm{M}$, respectively (Table 1), in accord with our previous estimates [12].

Table 1. Parameters of the one-site binding model describing the SPR sensograms for the interaction between HSA and monomeric $\mathrm{A} \beta_{40} / \mathrm{A} \beta_{42}$ in the absence/presence of SRO/TRP.

\begin{tabular}{|c|c|c|c|c|c|c|c|}
\hline \multirow[b]{2}{*}{ HSA Ligand } & \multirow{2}{*}{$\begin{array}{c}\text { [HSA } \\
\text { Ligand] }\end{array}$} & \multicolumn{3}{|c|}{$A \beta_{40}$} & \multicolumn{3}{|c|}{$A \beta_{42}$} \\
\hline & & $\begin{array}{c}k_{a} \times 10^{-3} \\
\mathbf{M}^{-1} \mathbf{s}^{-1}\end{array}$ & $\begin{array}{c}k_{d} \times 10^{4} \\
s^{-1}\end{array}$ & $\begin{array}{c}K_{D} \times 10^{7} \\
M\end{array}$ & $\begin{array}{c}k_{a} \times 10^{-3} \\
\mathbf{M}^{-1} \mathbf{s}^{-1}\end{array}$ & $\begin{array}{c}k_{d} \times 10^{4} \\
s^{-1}\end{array}$ & $\begin{array}{c}K_{D} \times 10^{7} \\
M\end{array}$ \\
\hline- & - & $0.7 \pm 0.3$ & $0.4 \pm 0.3$ & $0.6 \pm 0.3$ & $0.8 \pm 0.3$ & $0.7 \pm 0.3$ & $1.2 \pm 0.7$ \\
\hline \multirow{3}{*}{ SRO } & $10 \mu \mathrm{M}$ & $0.7 \pm 0.2$ & $0.26 \pm 0.03$ & $0.4 \pm 0.2$ & $0.6 \pm 0.4$ & $0.20 \pm 0.14$ & $0.4 \pm 0.2$ \\
\hline & $100 \mu \mathrm{M}$ & $1.5 \pm 1.2$ & $0.19 \pm 0.12$ & $0.15 \pm 0.13$ & $0.9 \pm 0.2$ & $0.08 \pm 0.02$ & $0.09 \pm 0.04$ \\
\hline & $1 \mathrm{mM}$ & $1.0 \pm 0.5$ & $0.09 \pm 0.05$ & $0.09 \pm 0.05$ & $1.2 \pm 0.2$ & $0.086 \pm 0.009$ & $0.070 \pm 0.015$ \\
\hline \multirow{3}{*}{ TRP } & $10 \mu \mathrm{M}$ & $0.7 \pm 0.2$ & $0.49 \pm 0.12$ & $0.8 \pm 0.4$ & $0.8 \pm 0.4$ & $0.4 \pm 0.2$ & $0.6 \pm 0.4$ \\
\hline & $100 \mu \mathrm{M}$ & $0.47 \pm 0.15$ & $0.53 \pm 0.17$ & $1.2 \pm 0.6$ & $0.5 \pm 0.3$ & $0.7 \pm 0.6$ & $1.8 \pm 1.8$ \\
\hline & $1 \mathrm{mM}$ & $0.6 \pm 0.2$ & $0.4 \pm 0.2$ & $0.7 \pm 0.4$ & $0.29 \pm 0.07$ & $0.18 \pm 0.07$ & $0.6 \pm 0.3$ \\
\hline
\end{tabular}




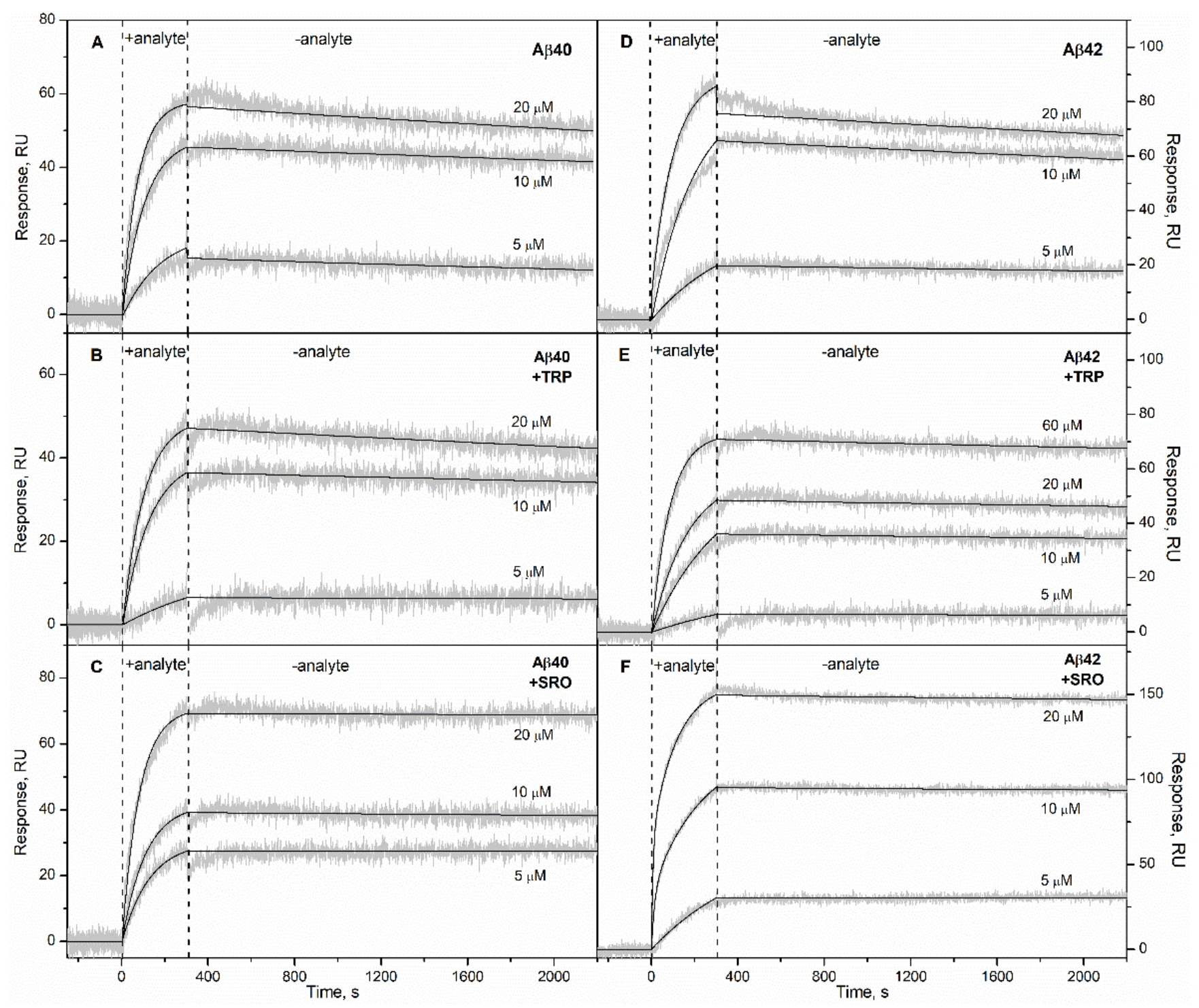

Figure 1. Ligand-dependent interaction of HSA with monomeric $\mathrm{A} \beta_{40} / \mathrm{A} \beta_{42}$ at $25{ }^{\circ} \mathrm{C}$ monitored by SPR spectroscopy (20 mM Tris- $\mathrm{HCl}, 140 \mathrm{mM} \mathrm{NaCl}, 4.9 \mathrm{mM} \mathrm{KCl}, 1 \mathrm{mM} \mathrm{MgCl} 2,2.5 \mathrm{mM} \mathrm{CaCl} 2, \mathrm{pH} 7.4$ ). A $\beta_{40} / \mathrm{A} \beta_{42}$ was immobilized on the sensor chip's surface by amine coupling. HSA concentrations are indicated nearby the sensograms for its interaction with $\mathrm{A} \beta_{40}$ (panels $\left.\mathbf{A}-\mathbf{C}\right)$ or $\mathrm{A} \beta_{42}(\mathbf{D}-\mathbf{F})$ in the absence $(\mathbf{A}, \mathbf{D})$ or presence of $1 \mathrm{mM}$ TRP $(\mathbf{B}, \mathbf{E})$ or $1 \mathrm{mM}$ SRO $(\mathbf{C}, \mathbf{F})$. The grey curves are experimental, while the black curves are theoretical, calculated according to the one-site binding model (see Table 1 for the fitting parameters).

Addition of $1 \mathrm{mM}$ TRP to the solution is sufficient to load HSA with TRP, considering the equilibrium association constant of $2.7 \times 10^{4} \mathrm{M}^{-1}$ [20]. Nevertheless, $1 \mathrm{mM}$ TRP did not affect HSA's apparent affinity to $A \beta_{40} / A \beta_{42}$ (Figures 1 and 2, Table 1). Instead, it notably changed the kinetics of the HSA-A $\beta_{42}$ interaction, inducing slowdown of the association and dissociation processes (see Figure 3). Meanwhile, addition of $1 \mathrm{mM}$ SRO decreased the apparent $K_{D}$ value for the HSA-A $\beta$ complex by a factor of 7 and 17 , for $\mathrm{A} \beta_{40}$ and $A \beta_{42}$, respectively (Figure 1, Table 1 ), mostly due to a slowdown of the dissociation process (Figure 3). A decrease in the SRO concentration to $10 \mu \mathrm{M}$ was accompanied by an increase in the apparent $K_{D}$ up to the values observed in the absence of the ligand (Figure 2, Table 1). Since the equilibrium dissociation constant for the HSA-SRO complex is $1.6 \mu \mathrm{M}$ [21], $10 \mu \mathrm{M}$ SRO is enough to saturate HSA with SRO. For this reason, the absence of noticeable effects of $10 \mu \mathrm{M}$ SRO on HSA's affinity to $A \beta$ indicates that SRO binding to HSA alone is insufficient for improvement of its affinity to $A \beta$, thereby suggesting the necessity of direct SRO interaction with $A \beta$ for that. The latter phenomenon is indicated 
by the efficient inhibition of $A \beta_{42}$ fibrillation by 50-100 $\mu \mathrm{M}$ SRO [22]. Notably, TRP was markedly less effective in this sense. The direct interaction of SRO with both A $\beta$ and HSA implies that the equilibrium and kinetic dissociation/association constants determined by SPR spectroscopy for HSA-A $\beta$ interaction in the presence of SRO(TRP) represent the apparent values, effectively describing the complex network of the multiple chemical equilibria occurring in the system.

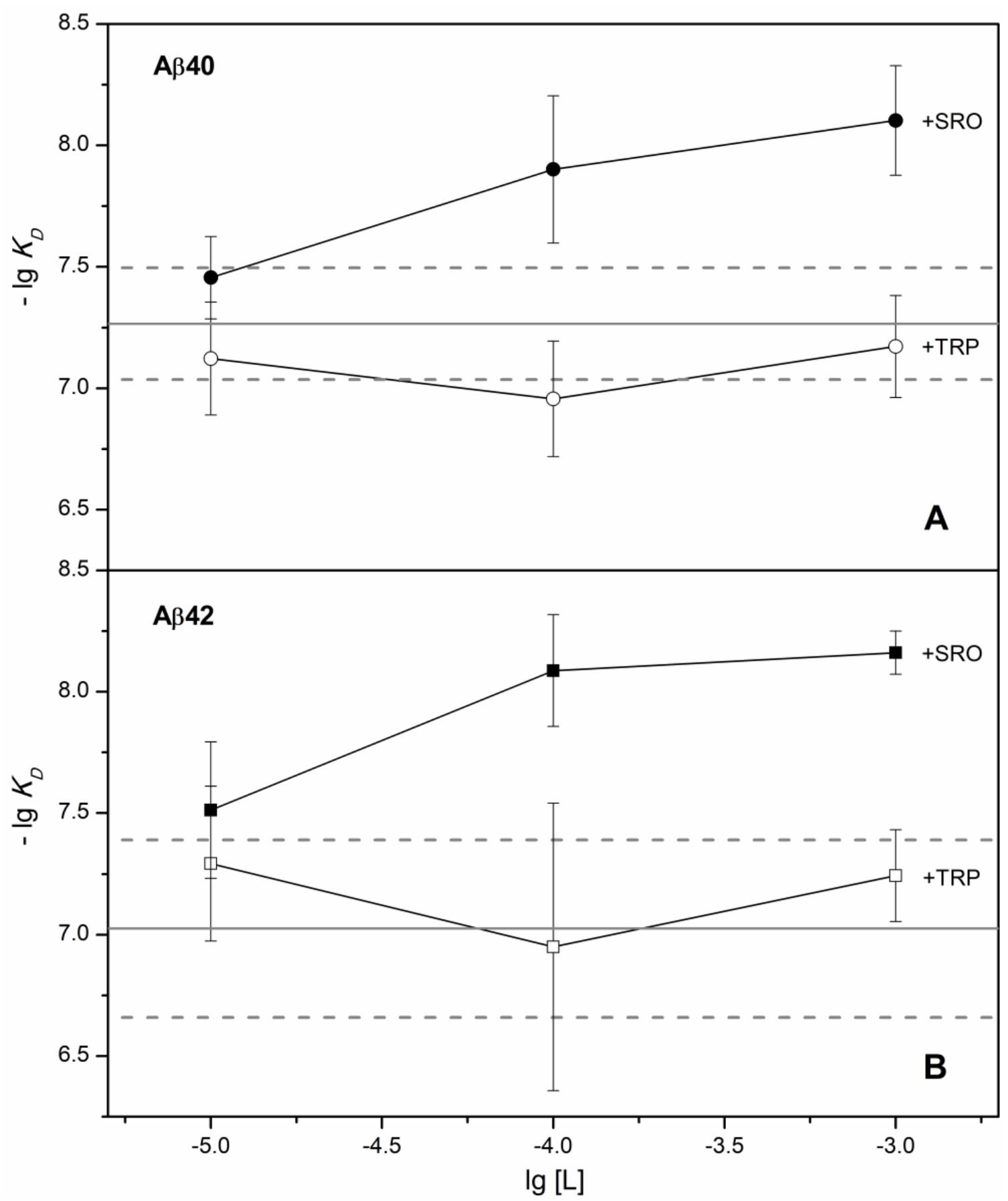

Figure 2. Influence of SRO/TRP (denoted as ' $L$ ') on the effective equilibrium dissociation constant, $K_{D}$, for the HSA complex with monomeric $A \beta_{40}$ (panel $\mathbf{A}$ ) or $A \beta_{42}(\mathbf{B})$, according to SPR data (see Table 1). The average-lg $K_{D}$ values for the HSA-A $\beta_{40} / A \beta_{42}$ complexes in the absence of the ligands are marked by solid gray lines, and their boundary values considering standard deviations are indicated by dashed gray lines. 

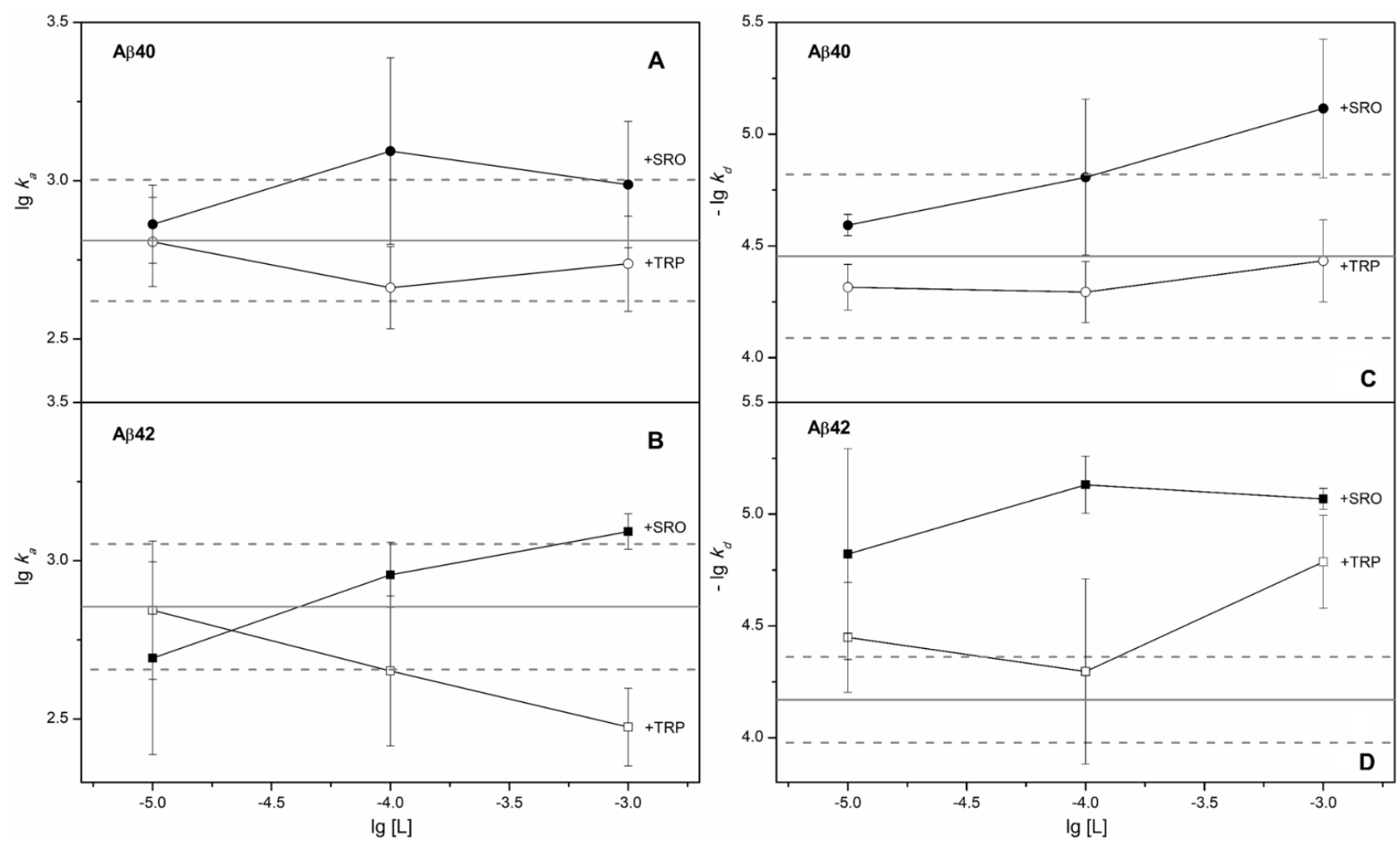

Figure 3. Influence of SRO/TRP on the association and dissociation processes. Effect of the SRO/TRP on the effective kinetic association constant, $k_{a}$, for HSA interaction with monomeric A $\beta 40$ (panel A) or A $\beta 42$ (B), according to SPR data (see Table 1). The average $\lg k_{a}$ values for the HSA-A $\beta 40 / 42$ complexes in the absence of the ligands are marked by solid gray lines, and their boundary values considering standard deviations are indicated by dashed gray lines. Influence of SRO/TRP on the effective kinetic dissociation constant, $k_{d}$, for the HSA complex with monomeric A $\beta 40$ (panel C) or A $\beta 42$ (D), according to SPR data (see Table 1). The average-lg $k_{d}$ values for the HSA-A $\beta 40 / 42$ complexes in the absence of the ligands are marked by solid gray lines, and their boundary values considering standard deviations are indicated by dashed gray lines.

The drastic difference between the effects exerted by SRO and TRP on the HSA-A $\beta$ interaction may partly arise due to the structural differences between HSA complexes with SRO/TRP. The SRO/TRP-induced changes in the quaternary structure of HSA were explored by crosslinking with glutaraldehyde at $37^{\circ} \mathrm{C}$, followed by SDS-PAGE analysis (Figure $4 \mathrm{~A})$. Intact HSA is mostly monomeric $(66 \%)$ with minor contributions of dimeric/trimeric and high-molecular-weight forms (about $23 \%$ and $12 \%$, respectively), consistent with the previous observations [23]. While addition of $1 \mathrm{mM}$ TRP did not affect the quaternary structure of HSA, addition of $1 \mathrm{mM} \mathrm{SRO}$ was accompanied by an approximately 2-fold increase in the content of high-molecular-weight forms at the expense of the monomer. Dynamic light scattering spectroscopy confirmed that SRO binding to HSA induces more prominent accumulation of its multimeric forms, compared with the effects induced by TRP (Figure 4B). Overall, SRO binding caused more distinct changes in the quaternary structure of HSA, relative to the TRP-induced effects. 

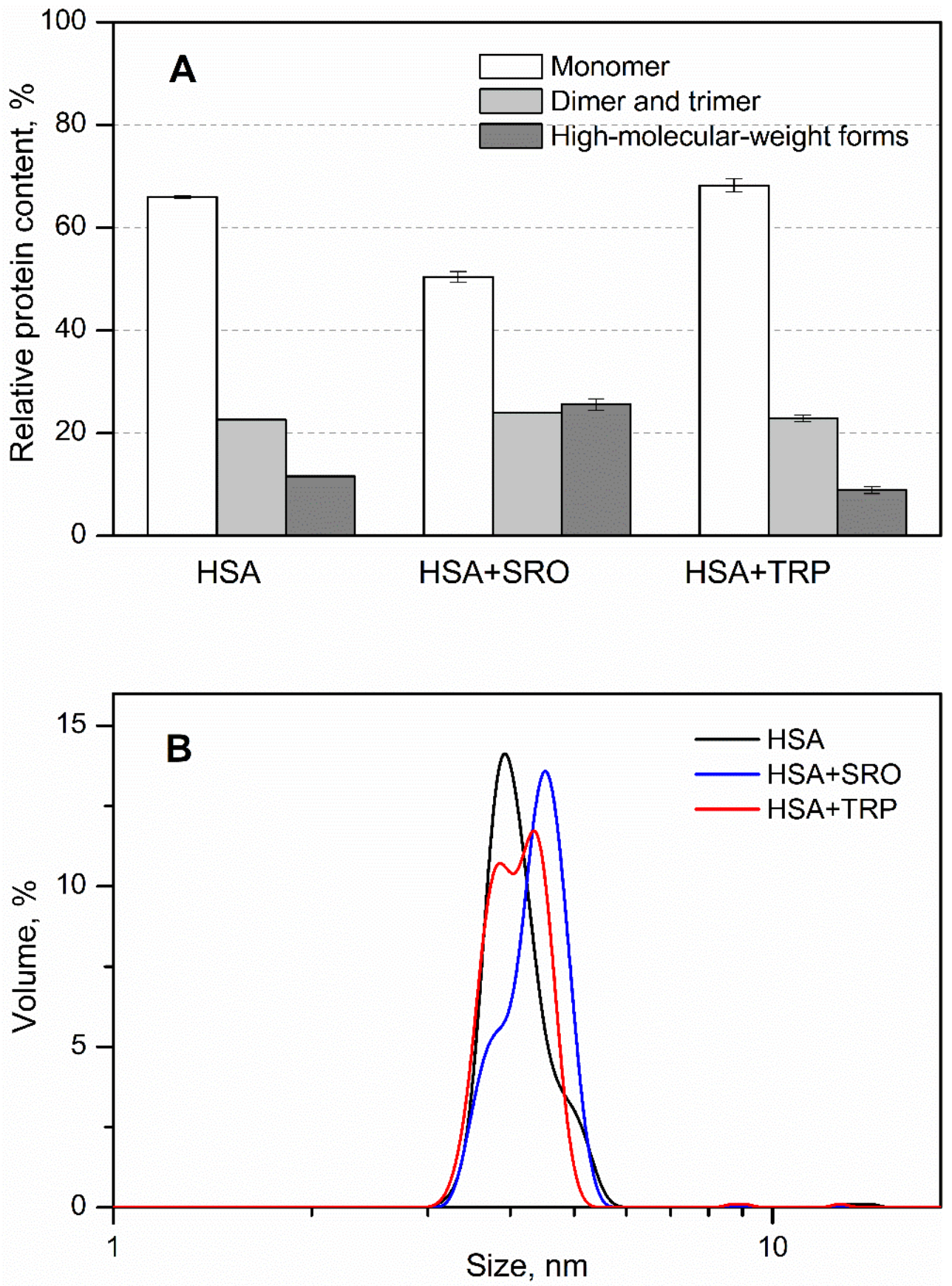

Figure 4. Influence of SRO/TRP $(1 \mathrm{mM})$ on the distribution of HSA $(36 \mu \mathrm{M})$ over multimeric forms, as judged from glutaraldehyde crosslinking experiments at $37{ }^{\circ} \mathrm{C}$ (panel A) and DLS at $25{ }^{\circ} \mathrm{C}$ (B) (20 mM HEPES-KOH, $140 \mathrm{mM} \mathrm{NaCl}, 4.9 \mathrm{mM} \mathrm{KCl}, 1 \mathrm{mM} \mathrm{MgCl} 2,2.5 \mathrm{mM} \mathrm{CaCl}_{2}, \mathrm{pH}$ 7.4). The standard deviations are indicated.

Since tertiary structures of HSA complexes with SRO/TRP have not been reported to date, we predicted the location of a SRO/TRP-binding pocket in HSA using the DoGSiteScorer algorithm [24]. According to these predictions, the binding site is located in the region between the IB site, 'IIA: Drug site 1', and 'IIIA: Drug site 2' [25] (Figure 5). 
A

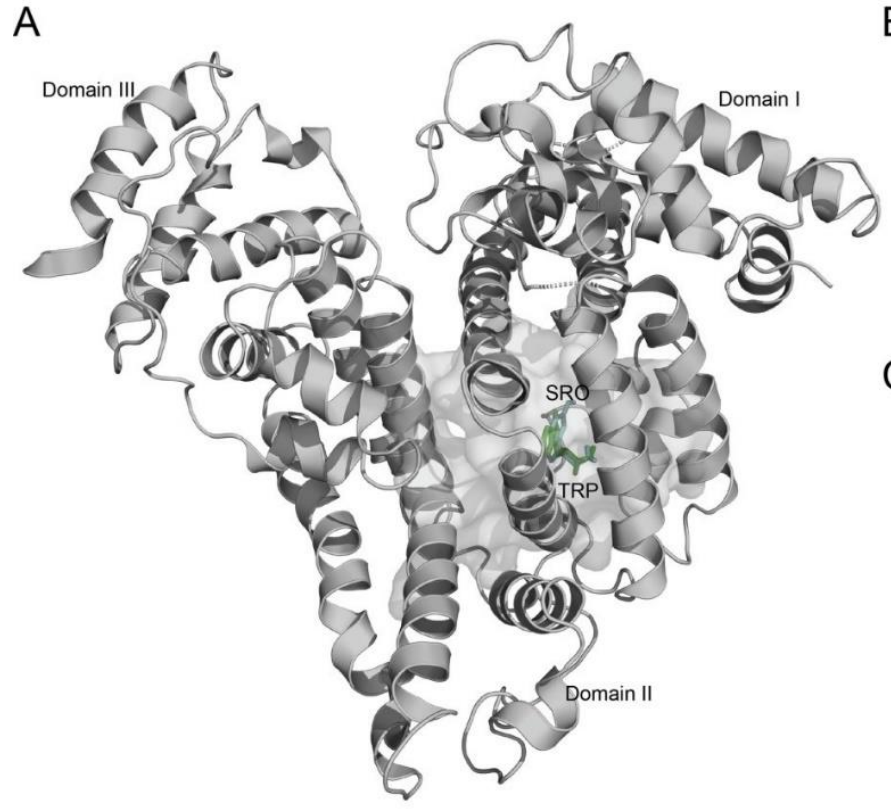

B

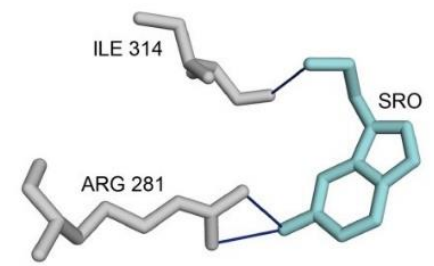

C

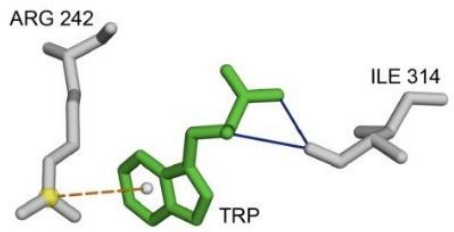

- - $\pi$-cation interactions

Hydrogen bond

Figure 5. Overlay of model tertiary structures of HSA-SRO/TRP complexes predicted using AutoDock Vina software [26], visualized with PyMOL (panel A). The ligand-binding pocket (grey) is represented as a surface. Representation of HSA residues interacting with SRO (cyan) (B) and TRP (green) (C).

The binding pocket is predominantly apolar, but contains charged residues and clusters of polar residues (Tyr174 of domain I; Ser216, Gln245, Ser311, Tyr365, Ser366 of domain II; Cys472, Tyr476, Ser478 of domain III): Y174, E177, S216, K219, Q220, L222, K223, F235, W238, A239, R242, L243, Q245, R246, F247, L258, L262, H266, R281, L284, A285, I288, L299, K310, S311, H312, I314, A315, E316, E318, D320, P363, Y365, S366, V367, V368, K468, P471, C472, D475, Y476, S478, V479. Molecular docking of HSA with SRO/TRP using AutoDock Vina software [26] predicted the difference in their orientation within the binding pocket (Figure 5; see Supplementary PDB files in Supplementary Materials). Analysis of interactions between HSA and the bound ligands using PLIP software [27] revealed specific hydrogen bonds and $\pi$-cation interactions (Table 2, Figure $5 B, C$ ). Overall, although the molecular modeling predicted the same binding HSA pocket for SRO/TRP, noticeable differences in structural peculiarities of microenvironments of the bound SRO/TRP molecules were also detected, which may have led to the differences in the HSA structural rearrangements in response to the binding of these ligands.

Table 2. The interactions between SRO/TRP and HSA within the model of their complex shown in Figure 5. The distance between donor and acceptor atoms is indicated for hydrogen bonds.

\begin{tabular}{|c|c|c|c|c|}
\hline Ligand & Index & Residue \# & Residue & Distance, Å \\
\hline \multirow{4}{*}{ SRO } & \multicolumn{4}{|c|}{ Hydrogen bonds } \\
\hline & 1 & 281 & Arg & 3.16 \\
\hline & 2 & 281 & Arg & 3.18 \\
\hline & 3 & 314 & Ile & 2.22 \\
\hline \multirow{5}{*}{ TRP } & \multicolumn{4}{|c|}{ Hydrogen bonds } \\
\hline & 1 & 314 & Ile & 2.99 \\
\hline & 2 & 314 & Ile & 3.21 \\
\hline & \multicolumn{4}{|c|}{$\pi$-cation interactions } \\
\hline & 1 & 242 & Arg & 5.57 \\
\hline
\end{tabular}


To explore the conformational flexibility of the established SRO/TRP-binding pocket of HSA, we conducted a multiparametric evaluation of the protein predisposition for intrinsic disorder using a set of commonly utilized per-residue disorder predictors. In these analyses, a threshold of 0.5 is typically used to identify disordered residues and regions in a query protein. Residues with the disorder scores (DS) $0.25 \leq$ DS $<0.5$ are considered to be moderately disordered, whereas residues with $0.15 \leq \mathrm{DS}<0.25$ are flexible. The results of this analysis are shown in Figure 6, which clearly illustrate that most of the residues involved in the binding to TRP or SRO are characterized by high conformational flexibility. In fact, with a very few exceptions, all such residues are located within regions that are predicted to be flexible/disordered by at least six predictors. Importantly, the several residues are predicted to have a propensity for ordering. This observation suggests that the interplay between intrinsic (amino acid sequence-based) structural flexibility and order propensity is important to accommodating TRP/SRO in the binding site, similarly to the target recognition principle established for S100 proteins [28]. Overall, the disorder propensity predictions suggest that SRO/TRP binding to HSA is not of the "lock-and-key" type but is likely to follow the "induced fit" mechanism.

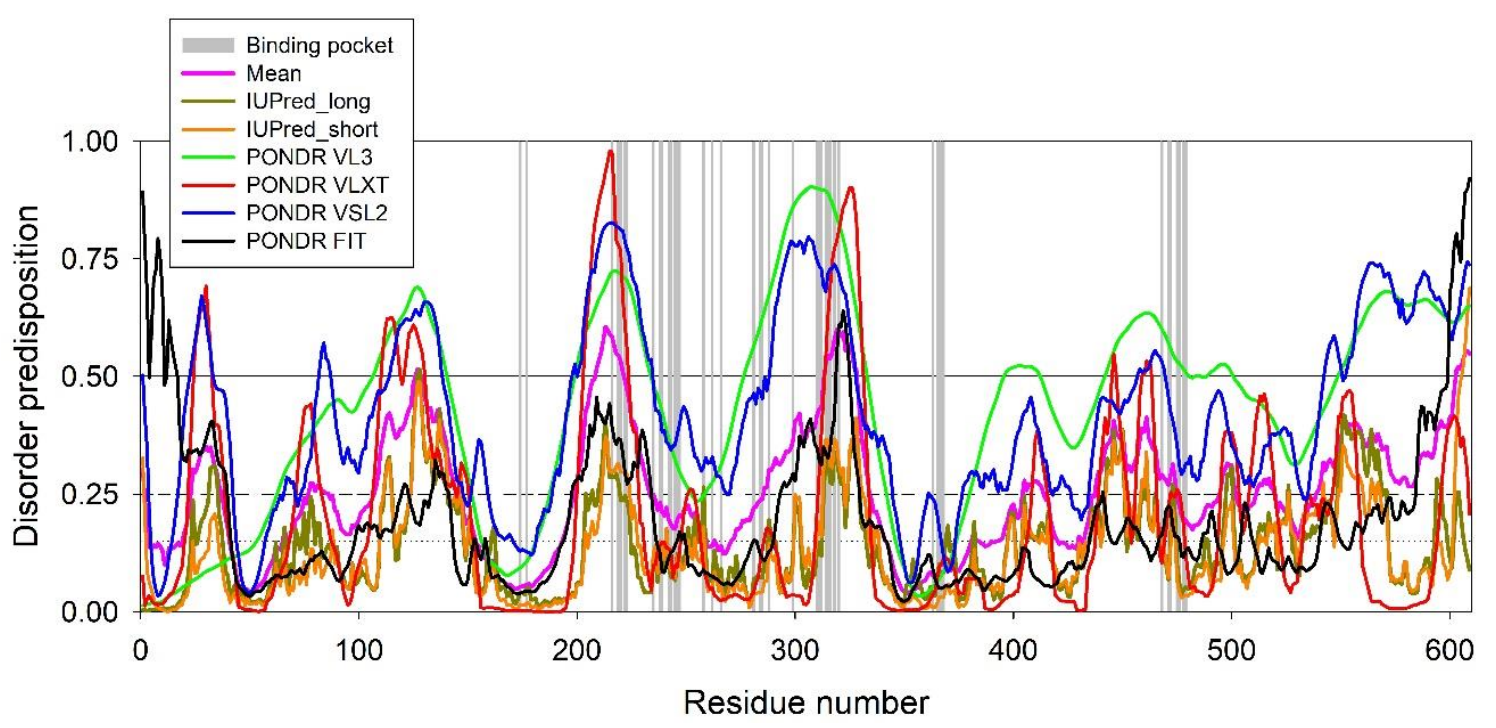

Figure 6. Bioinformatics analysis of the disorder predisposition of the full-length HSA (UniProt ID: P02768), including the signal peptide (residues 1-18) and the pro-peptide (residues 19-24). Intrinsic disorder profiles were generated based on the commonly used disorder predictors PONDR ${ }^{\circledR}$ VLXT [29], PONDR ${ }^{\circledR}$ VL3 [30], PONDR ${ }^{\circledR}$ VLS2B [31], PONDR ${ }^{\circledR}$ FIT [32], IUPred2 (Short), and IUPred2 (Long) [33,34]. Mean disorder scores (DS) calculated by averaging the outputs of individual predictors are shown as well. The outputs of the disorder predictors are represented as real numbers between 1 (ideal prediction of disorder) and 0 (ideal prediction of order). A threshold of 0.5 was used to identify disordered residues and regions in HSA. Residues with $0.25 \leq \mathrm{DS}<0.5$ are considered as moderately disordered, whereas residues with $0.15 \leq \mathrm{DS}<0.25$ are flexible. The position of residues involved in TRP/SRO binding is shown by gray vertical bars.

\section{Discussion}

The literature data on HSA interaction with monomeric $A \beta$ are contradictory $[7,35-38]$. While some studies did not detect HSA interaction with monomeric $A \beta[35,36]$, other studies confirmed it $[7,37,38]$, but gave affinity estimates differing from those reported here and in our previous work [12]. These contradictions seem to arise due to the high propensity of $A \beta$ for multimerization, leading to sensitivity of the experiments to many factors, including the source of $A \beta$ samples (recombinant or synthetic), the $A \beta$ pretreatment procedures and solvent conditions (confirmed in [12]), and the methods used for the analysis. To ensure the monomeric state of $A \beta$ in our experiments, we used the previously validated approach based on A $\beta$ immobilization on the surface of a SPR chip by amine coupling, followed by removal of the non-covalently bound A $\beta$ molecules with SDS [12]. 
Previously, we showed the ability of linoleic and arachidonic acids to favor interaction between HSA and monomeric $A \beta_{40} / A \beta_{42}$ with a 3-fold decrease in the $K_{D}$ value [12]. The data on SRO's effect on the HSA-A $\beta$ equilibrium presented here illustrate the much higher potential for modulation of this equilibrium by low-molecular-weight HSA ligands with up to a 17-fold decrease in the $K_{D}$ value. Such a dramatic change in HSA's affinity for A $\beta$ could be achieved via the following mechanisms or their combination: (I) an allosteric mechanism (ligand binding to HSA, altering its affinity for A $\beta$ ); or (II) ligand binding to $A \beta$, affecting its interaction with HSA. In the case of mechanism I alone, the SRO-induced changes in HSA's affinity for A $\beta$ would be noticeable at SRO concentrations above $1.6 \mu \mathrm{M}$ (the $K_{D}$ value for the HSA-SRO complex [21]).

The absence of a marked influence of $10 \mu \mathrm{M}$ SRO on the HSA-A $\beta$ interaction points out the contribution of mechanism II. This conclusion is in line with the data on the potent inhibition of $A \beta_{42}$ fibrillation by $50-100 \mu \mathrm{M}$ SRO [22], which corresponds to the SRO level ensuring notable changes in HSA's affinity for A $\beta$. Despite the similar structures of SRO and TRP, the latter did not affect HSA's effective affinity for A $\beta$ but slowed their association and dissociation. The drastic difference between SRO/TRP actions on the HSA-A $\beta$ equilibrium can be rationalized within the same mechanisms I and II. The notable difference in quaternary structures of HSA in complex with SRO/TRP and distinct structural differences between HSA-SRO/TRP complexes predicted by molecular docking evidence that SRO binding and TRP binding differently alter HSA's structure. Meanwhile, the much less efficient inhibition of $A \beta_{42}$ fibrillation by TRP, compared with SRO [22], indicates the possibility of the differences between SRO and TRP in their interaction with monomeric $A \beta$.

The revealed influence of SRO on the HSA-A $\beta$ interaction could be relevant to AD progression, considering the disintegration of the serotonergic system during $\mathrm{AD}$, accompanied by a decrease in the SRO level in biofluids $[15,16,39]$. The SRO concentration in plasma is $0.28-1.7 \mu \mathrm{M}$ [40], but in the synaptic cleft it may reach $6 \mathrm{mM}$ and $55 \mathrm{nM}$ after SRO diffuses into the extracellular compartment [41]. Hence, the peak SRO level in the central nervous system is sufficient for modulation of the HSA-A $\beta$ interaction. Therefore, the decrease in the $A \beta$ level in interstitial brain fluid observed in response to either administration of SSRIs or direct infusion of SRO into the hippocampus in a mouse model of AD [42] could be partly due to the facilitated trapping of A $\beta$ by HSA. Chronic treatment with a SSRI caused a $50 \%$ reduction in plaque load in mouse brain, and the same effect has been confirmed for cognitively normal elderly participants chronically exposed to antidepressant drugs [42]. Thus, the principal finding of this work provides an alternative explanation to the available literature data on the SRO-induced reduction in the $A \beta$ level in interstitial brain fluid and the respective decrease in brain amyloid load, thereby highlighting the importance of SRO for proper buffering of $A \beta$ by HSA.

Since chemical structures of agents in clinical studies in AD, including SSRIs aimed at increasing the SRO level at nerve terminals $[18,43]$, indicate their ability to interact with HSA or/and $A \beta$, it would be reasonable to complement their trials by tests of the ability of the drug candidates to affect the HSA-A $\beta$ interaction.

\section{Materials and Methods}

\subsection{Materials}

A fatty-acid-free HSA sample prepared under non-denaturing conditions (\#126654) [19] was purchased from Merck (Darmstadt, Germany). Ultra-pure recombinant human A $\beta_{42}$ produced in E. coli (\#A-1163-1) was obtained from rPeptide (Watkinsville, GA, USA). Usp2cC was prepared mainly as described in [44]. The SRO (\#B21263) was from Alfa Aesar (Kandel, Germany). The TRP (\#A1645) and HEPES were from AppliChem (Darmstadt, Germany). Ultra-grade Tris and 2-ME were purchased from VWR Life Science AMRESCO (Vienna, Austria). The sodium chloride, potassium chloride, urea, and SDS were from Panreac Applichem (Darmstadt, Germany). The calcium chloride and magnesium chloride were from Fluka (Charlotte, NC, USA). Ethylenediaminetetraacetic acid (EDTA), grade 
II glutaraldehyde, and acetonitrile were from Merck (Darmstadt, Germany). $\mathrm{NH}_{4} \mathrm{OH}$ and acetic acid were purchased from Component-reaktiv (Moscow, Russia) and Labteh (Moscow, Russia), respectively. Trifluoroacetic acid (TFA) was bought from Fisher Sci (Waltham, MA, USA). Dimethyl sulfoxide (DMSO) was purchased from Helicon (Moscow, Russia). Ethanolamine and Profinity ${ }^{\mathrm{TM}}$ IMAC Resin were obtained from Bio-Rad Laboratories (Hercules, CA, USA). A Jupiter C18 column was purchased from Phenomenex ${ }^{\circledR}$ (Torrance, CA, USA).

Protein concentrations were measured spectrophotometrically using molar extinction coefficients at $280 \mathrm{~nm}$ calculated according to [45]: $34,445 \mathrm{M}^{-1} \mathrm{~cm}^{-1}$ for HSA and $1490 \mathrm{M}^{-1} \mathrm{~cm}^{-1}$ for $\mathrm{A} \beta_{40} / \mathrm{A} \beta_{42}$.

\subsection{Expression and Purification of Recombinant Human $A \beta_{40}$}

Human $A \beta_{40}$ was expressed in E. coli and purified as described earlier [12] with some modifications. The 2-Mercaptoethanol (2-ME) concentration in the buffers was $5 \mathrm{mM}$. The $6 \times$ His-ubiquitin- $\mathrm{A} \beta_{40}$ fusion protein was dialyzed twice against $50 \mathrm{mM}$ Tris- $\mathrm{HCl}$ and $5 \mathrm{mM}$ 2-ME ( $\mathrm{pH}$ 8.6) buffers containing $6 \mathrm{M}$ and $4 \mathrm{M}$ urea, respectively. $\mathrm{A} \beta_{40}$ was excised from the fusion protein via incubation with Usp2-cc (50-fold molar excess of the fusion over the enzyme) at room temperature for $3 \mathrm{~h}$. Urea was added to the solution up to $8 \mathrm{M}$. The hydrolysate was passed through a Profinity IMAC column equilibrated with $50 \mathrm{mM}$ Tris- $\mathrm{HCl}, 5 \mathrm{mM}$ 2-ME, and $8 \mathrm{M}$ urea $(\mathrm{pH} 8.0-8.5)$ to remove His-tagged ubiquitin and Usp2-cc. $\mathrm{A} \beta_{40}$ was purified by chromatography on an HPLC Jupiter C18 column (buffer A: $20 \mathrm{mM} \mathrm{NH}_{4}{ }^{+}, 6 \mathrm{mM}$ acetic acid, $\mathrm{pH}$ 9.6; buffer B: 70\% acetonitrile; gradient steps: loading of the sample in $15 \%$ buffer B, flushing by $25 \%$ buffer B for $10 \mathrm{~min}$, linear gradient from $28 \%$ to $45 \%$ buffer B for $80 \mathrm{~min}$ ). Precise chain cleavage by Usp2-cc was confirmed by electrospray ionization mass spectrometry (LCMS-2010EV, Shimadzu, Kyoto, Japan). The purified $\mathrm{A} \beta_{40}$ samples were freeze-dried and stored at $-70^{\circ} \mathrm{C}$.

\subsection{Pretreatment of $A \beta$ Samples for SPR Experiments}

Recombinant human $A \beta_{40} / A \beta_{42}$ samples were pretreated for SPR measurements mainly as described in [46]. The freeze-dried A $\beta$ sample was dissolved in neat TFA at a concentration of $0.5-1 \mathrm{mg} / \mathrm{mL}$. The solution was sonicated for $30 \mathrm{~s}$. TFA was evaporated using Eppendorf Concentrator plus. The dried A $\beta$ sample was dissolved in DMSO at a concentration of $2 \mathrm{mg} / \mathrm{mL}$, and stored at $-20^{\circ} \mathrm{C}$.

\subsection{Surface Plasmon Resonance Studies}

SPR measurements were performed at $25{ }^{\circ} \mathrm{C}$ using a Bio-Rad ProteOn ${ }^{\mathrm{TM}}$ XPR36 instrument mainly as previously described [12]. Ligand $(57 \mu \mathrm{g} / \mathrm{mL}$ recombinant human $\mathrm{A} \beta_{40} / \mathrm{A} \beta_{42}$ in $10 \mathrm{mM}$ sodium acetate, $\mathrm{pH} 4.5$ buffer) was immobilized on a ProteOn GLH sensor chip surface (up to 7000-9000 RUs) by amine coupling. The remaining activated amine groups on the chip surface were blocked by $1 \mathrm{M}$ ethanolamine solution. The noncovalently bound $A \beta_{40} / A \beta_{42}$ molecules were washed from the chip surface with $2 \%$ SDS water solution until stabilization of the signal [12]. The monomeric state of $A \beta$ was previously verified by use of a polyclonal antibody selective to $A \beta$ oligomers (A11) or an anti-A $\beta_{20}$ monoclonal antibody (7N22) as the analyte [12]; the immobilized $A \beta$ sample did not reveal changes in the SPR signal upon application of A11 but interacted with 7N22. Analyte (5-60 $\mu \mathrm{M}$ HSA) in the running buffer $(20 \mathrm{mM}$ Tris- $\mathrm{HCl}, 140 \mathrm{mM} \mathrm{NaCl}$, $4.9 \mathrm{mM} \mathrm{KCl}, 1 \mathrm{mM} \mathrm{MgCl} 2,2.5 \mathrm{mM} \mathrm{CaCl}_{2}, \mathrm{pH} 7.4$ ) was passed over the chip at a rate of $30 \mu \mathrm{L} / \mathrm{min}$ for $300 \mathrm{~s}$, followed by flushing the chip with the running buffer for $2400 \mathrm{~s}$. The sensor chip surface was regenerated by passage of $10 \mathrm{mM}$ EDTA pH 7.9 solution containing $2 \%$ SDS. The influence of HSA ligands on its interaction with $A \beta_{40} / A \beta_{42}$ was studied in the presence of TRP/SRO $(10 \mu \mathrm{M}, 100 \mu \mathrm{M}$, or $1 \mathrm{mM})$. The double-referenced SPR sensograms were globally fitted according to the one-site binding model using Bio-Rad ProteOn Manager ${ }^{\mathrm{TM}}$ v.3.1 software. The effective equilibrium $\left(K_{D}\right)$ and kinetic $\left(k_{d}\right.$ and $\left.k_{a}\right)$ 
dissociation/association constants were evaluated for each HSA concentration, followed by averaging of the resulting values (standard deviations are indicated).

\subsection{Chemical Crosslinking of Proteins}

Crosslinking of HSA $(36 \mu \mathrm{M})$ with $0.02 \%$ glutaraldehyde was performed in $20 \mathrm{mM}$ HEPES-KOH, $140 \mathrm{mM} \mathrm{NaCl}, 4.9 \mathrm{mM} \mathrm{KCl}, 1 \mathrm{mM} \mathrm{MgCl}_{2}, 2.5 \mathrm{mM} \mathrm{CaCl}_{2}$, pH 7.4 buffer in the absence/presence of $1 \mathrm{mM} \mathrm{SRO} / \mathrm{TRP}$ at $37^{\circ} \mathrm{C}$ for $1 \mathrm{~h}$, mainly as described in [23].

\subsection{Dynamic Light Scattering Studies}

DLS measurements of HSA ( $36 \mu \mathrm{M})$ solutions in $20 \mathrm{mM}$ HEPES-KOH, $140 \mathrm{mM} \mathrm{NaCl}$, $4.9 \mathrm{mM} \mathrm{KCl}, 1 \mathrm{mM} \mathrm{MgCl} 2,2.5 \mathrm{mM} \mathrm{CaCl} 2, \mathrm{pH} 7.4$ buffer in the absence/presence of $1 \mathrm{mM}$ SRO/TRP were performed at $25.0^{\circ} \mathrm{C}$ using a Zetasizer Nano ZS spectrometer (Malvern Instruments Ltd., Malvern, UK). The back-scattered light from a $4 \mathrm{~mW} \mathrm{He} / \mathrm{Ne}$ laser $(632.8 \mathrm{~nm})$ was collected at an angle of $173^{\circ}$. The acquisition time for a single autocorrelation function was $45 \mathrm{~s}$. The resulting autocorrelation functions are averaged values from 20 measurements. The volume-size distributions were calculated using the following parameters: a refractive index of 1.330 and a viscosity value of $0.8882 \mathrm{cP}$.

\subsection{Prediction of Ligand-Binding Sites in HSA}

The X-ray structure of HSA was obtained from Protein Data Bank [47] entry 1UOR (chain A). Water molecules were removed from the structure, while hydrogen atoms were added, using AutoDockTools software (http://autodock.scripps.edu/resources/ adt/index_html, accessed on 28 April 2021). The three-dimensional structures of SRO and TRP were obtained from the PubChem database (https:/ / www.ncbi.nlm.nih.gov/ pccompound, accessed on 28 April 2021) and converted into PDB format using PyMOL v.1.6.9.0 software (https:/ / pymol.org/2/, accessed on 28 April 2021). SRO/TRP-binding pockets of HSA were identified using the DoGSiteScorer algorithm [24] implemented in the ProteinsPlus service (https:/ / proteins.plus/, accessed on 28 April 2021). AutoDock Vina (http:/ / vina.scripps.edu/index.html, accessed on 28 April 2021) [26] was used for molecular docking. The resulting model HSA-SRO/TRP complexes were visualized using PyMOL v.1.6.9.0. Characterization of the protein-ligand interactions was performed by the PLIP service (https: / / plip-tool.biotec.tu-dresden.de/plip-web / plip/index, accessed on 28 April 2021) [27] using numbering of the residues according to UniProt entry P02768.

\subsection{Evaluation of the Per-Residue Intrinsic Disorder Predisposition of HSA}

The intrinsic disorder predisposition of HSA was analyzed by commonly used perresidue predictors, including PONDR ${ }^{\circledR}$ VLXT [29], PONDR ${ }^{\circledR}$ VSL2 [31], and PONDR ${ }^{\circledR}$ VL3 [30], which are available on the PONDR site (http:/ / www.pondr.com, accessed on 28 April 2021), PONDR ${ }^{\circledR}$ FIT, which is a meta-predictor that incorporates predictions from several different sources [32], and the IUPred computational platform that allows for identification of either short or long regions of intrinsic disorder, IUPred Long and IUPred_Short [33]. We utilized the DiSpi web crawler, which was designed for the rapid prediction and comparison of protein disorder profiles. It aggregates the results from a number of well-known disorder predictors: PONDR ${ }^{\circledR}$ VLXT [29], PONDR ${ }^{\circledR}$ VL3 [30], PONDR $^{\circledR}$ VLS2B [31], PONDR ${ }^{\circledR}$ FIT [32], IUPred2_Short, and IUPred2_Long [33,34]. The outputs of the disorder predictors are represented as real numbers between 1 (ideal prediction of disorder) and 0 (ideal prediction of order). A threshold of $\geq 0.5$ was used to identify disordered residues and regions in HSA. Residues with the disorder scores (DS) $0.25 \leq \mathrm{DS}<0.5$ are considered to be moderately disordered, whereas residues with $0.15 \leq \mathrm{DS}<0.25$ are flexible.

\section{Conclusions}

The presented example of ligand-induced facilitation of HSA interaction with monomeric $\mathrm{A} \beta$ demonstrates the high potential for pharmacological modulation of this interaction 
aimed at decreasing the free $A \beta$ concentration, leading to the inhibition of malicious $A \beta$ deposits. The revealed effect seems to involve ligand binding to both participants of the reaction. The data deepen our understanding of the SRO-mediated effects reported in animal and clinical studies.

Supplementary Materials: The following are available online at https://www.mdpi.com/article/10.3 390/ijms22115896/s1.

Author Contributions: Conceptualization, E.A.L. and S.E.P.; methodology, A.S.K. and E.I.D.; validation, E.A.L., A.S.K., E.I.D., E.L.N., V.N.U. and S.E.P.; formal analysis, E.A.L., A.S.K., E.I.D., E.L.N., M.P.S., A.A.N., M.E.P., E.V.R., V.N.U. and S.E.P.; investigation, E.A.L., A.S.K., E.I.D., E.L.N., M.P.S., A.A.N., M.E.P., E.V.R., V.N.U. and S.E.P.; resources, E.A.L. and S.E.P.; data curation, E.A.L., V.N.U. and S.E.P.; writing - original draft preparation, E.A.L., A.S.K., E.I.D., E.L.N., V.N.U. and S.E.P.; writingreview and editing, E.A.L., V.N.U. and S.E.P.; intrinsic disorder analysis, V.N.U.; visualization, E.A.L., A.S.K., E.I.D., E.L.N., V.N.U. and S.E.P.; supervision, E.A.L. and S.E.P.; project administration, E.A.L. and S.E.P.; funding acquisition, E.A.L. All authors have read and agreed to the published version of the manuscript.

Funding: This work was supported by a grant to E.A.L. from the Russian Science Foundation (No. 20-74-10072).

Institutional Review Board Statement: Not applicable.

Informed Consent Statement: Not applicable.

Data Availability Statement: Not applicable.

Acknowledgments: We are indebted to Victoria A. Rastrygina (Pushchino, Russia) for help in the preparation of $A \beta$ samples, and to Eugene A. Permyakov (Pushchino, Russia) for language editing of the manuscript.

Conflicts of Interest: The authors declare no conflict of interest. The funders had no role in the design of the study; in the collection, analyses, or interpretation of data; in the writing of the manuscript; or in the decision to publish the results.

$\begin{array}{ll}\text { Abbreviations } & \\ \text { 2-ME } & \text { 2-mercaptoethanol } \\ \text { A } \beta & \text { amyloid } \beta \text { peptide } \\ \text { A } \beta_{40} / \mathrm{A} \beta_{42} / \mathrm{A} \beta_{20} & \text { amyloid } \beta \text { peptide, residues 1-40/42/20 } \\ \text { AD } & \text { Alzheimer's disease } \\ \text { CSF } & \text { cerebrospinal fluid } \\ \text { DLS } & \text { dynamic light scattering } \\ \text { DMSO } & \text { dimethyl sulfoxide } \\ \text { DS } & \text { disorder score } \\ \text { EDTA } & \text { ethylenediaminetetraacetic acid } \\ \text { HEPES } & \text { 4-(2-hydroxyethyl)piperazine-1-ethanesulfonic acid } \\ \text { HSA } & \text { human serum albumin } \\ \text { PAGE } & \text { polyacrylamide gel electrophoresis } \\ \text { PDB } & \text { Protein Data Bank } \\ \text { RU } & \text { resonance unit } \\ \text { SDS } & \text { sodium dodecyl sulfate } \\ \text { SPR } & \text { surface plasmon resonance } \\ \text { SRO } & \text { serotonin, 5-hydroxytryptamine, 5-HT } \\ \text { SSRI } & \text { selective serotonin reuptake inhibitor } \\ \text { TFA } & \text { trifluoroacetic acid } \\ \text { Tris } & \text { tris(hydroxymethyl)aminomethane } \\ \text { TRP } & \text { L-tryptophan } \\ \text { Usp2-cc } & \text { ubiquitin carboxyl-terminal hydrolase 2, catalytic core } \\ & \end{array}$




\section{References}

1. Litus, E.A.; Permyakov, S.E.; Uversky, V.N.; Permyakov, E.A. Intrinsically disordered regions in serum albumin: What are they for? Cell Biochem. Biophys. 2017, 76, 39-57. [CrossRef]

2. Al-Harthi, S.; Lachowicz, J.I.; Nowakowski, M.E.; Jaremko, M.; Jaremko, L. Towards the functional high-resolution coordination chemistry of blood plasma human serum albumin. J. Inorg. Biochem. 2019, 198, 110716. [CrossRef]

3. Chen, G.-F.; Xu, T.-H.; Yan, Y.; Zhou, Y.-R.; Jiang, Y.; Melcher, K.; Xu, H.E. Amyloid beta: Structure, biology and structure-based therapeutic development. Acta Pharmacol. Sin. 2017, 38, 1205-1235. [CrossRef] [PubMed]

4. Biere, A.L.; Ostaszewski, B.; Stimson, E.R.; Hyman, B.T.; Maggio, J.E.; Selkoe, D.J. Amyloid beta-peptide is transported on lipoproteins and albumin in human plasma. J. Biol. Chem. 1996, 271, 32916-32922. [CrossRef]

5. Bohrmann, B.; Tjernberg, L.; Kuner, P.; Poli, S.; Levet-Trafit, B.; Naslund, J.; Richards, G.; Huber, W.; Dobeli, H.; Nordstedt, C. Endogenous proteins controlling amyloid beta-peptide polymerization. Possible implications for beta-amyloid formation in the central nervous system and in peripheral tissues. J. Biol. Chem. 1999, 274, 15990-15995. [CrossRef] [PubMed]

6. Stanyon, H.F.; Viles, J.H. Human serum albumin can regulate amyloid- $\beta$ peptide fiber growth in the brain interstitium: Implications for Alzheimer disease. J. Biol. Chem. 2012, 287, 28163-28168. [CrossRef]

7. Wang, C.; Cheng, F.; Xu, L.; Jia, L. HSA targets multiple A $\beta 42$ species and inhibits the seeding-mediated aggregation and cytotoxicity of A $\beta 42$ aggregates. RSC Adv. 2016, 6, 71165-71175. [CrossRef]

8. Ezra, A.; Rabinovich-Nikitin, I.; Rabinovich-Toidman, P.; Solomon, B. Chapter 11-Multifunctional effects of human serum albumin toward neuroprotection in Alzheimer disease. In Neuroprotection in Alzheimer's Disease; Gozes, I., Ed.; Academic Press: Cambridge, MA, USA, 2017; pp. 217-238.

9. Boada, M.; Ortiz, P.; Anaya, F.; Hernandez, I.; Munoz, J.; Nunez, L.; Olazaran, J.; Roca, I.; Cuberas, G.; Tarraga, L.; et al. Amyloid-targeted therapeutics in Alzheimer's disease: Use of human albumin in plasma exchange as a novel approach for Abeta mobilization. Drug News Perspect. 2009, 22, 325-339. [CrossRef]

10. Boada, M.; Anaya, F.; Ortiz, P.; Olazaran, J.; Shua-Haim, J.R.; Obisesan, T.O.; Hernandez, I.; Munoz, J.; Buendia, M.; Alegret, M.; et al. Efficacy and safety of plasma exchange with $5 \%$ albumin to modify cerebrospinal fluid and plasma amyloid-beta concentrations and cognition outcomes in Alzheimer's disease patients: A multicenter, randomized, controlled clinical trial. J. Alzheimers Dis. 2017, 56, 129-143. [CrossRef] [PubMed]

11. Boada, M.; Lopez, O.; Nunez, L.; Szczepiorkowski, Z.M.; Torres, M.; Grifols, C.; Paez, A. Plasma exchange for Alzheimer's disease management by albumin replacement (AMBAR) trial: Study design and progress. Alzheimer's Dement. 2019, 5, 61-69. [CrossRef]

12. Litus, E.A.; Kazakov, A.S.; Sokolov, A.S.; Nemashkalova, E.L.; Galushko, E.I.; Dzhus, U.F.; Marchenkov, V.V.; Galzitskaya, O.V.; Permyakov, E.A.; Permyakov, S.E. The binding of monomeric amyloid $\beta$ peptide to serum albumin is affected by major plasma unsaturated fatty acids. Biochem. Biophys. Res. Commun. 2019, 510, 248-253. [CrossRef] [PubMed]

13. Cole, G.M.; Ma, Q.-L.; Teter, B.; Jones, M.; Frautschy, S.A. [P3-124]: Dietary linoleic acid differentially influences brain fads activities increasing an N-6 metabolite that inhibits inflammation and promotes amyloid- $\beta$ clearance. Alzheimer's Dement. 2017, 13, P982. [CrossRef]

14. Bode, D.C.; Stanyon, H.F.; Hirani, T.; Baker, M.D.; Nield, J.; Viles, J.H. Serum albumin's protective inhibition of amyloid- $\beta$ fiber formation is suppressed by cholesterol, fatty acids and warfarin. J. Mol. Biol. 2018, 430, 919-934. [CrossRef]

15. Smith, G.S.; Barrett, F.S.; Joo, J.H.; Nassery, N.; Savonenko, A.; Sodums, D.J.; Marano, C.M.; Munro, C.A.; Brandt, J.; Kraut, M.A.; et al. Molecular imaging of serotonin degeneration in mild cognitive impairment. Neurobiol. Dis. 2017, 105, 33-41. [CrossRef]

16. Whiley, L.; Chappell, K.E.; D’Hondt, E.; Lewis, M.R.; Jiménez, B.; Snowden, S.G.; Soininen, H.; Kłoszewska, I.; Mecocci, P.; Tsolaki, M.; et al. Metabolic phenotyping reveals a reduction in the bioavailability of serotonin and kynurenine pathway metabolites in both the urine and serum of individuals living with Alzheimer's disease. Alzheimer's Res. Ther. 2021, 13, 20. [CrossRef] [PubMed]

17. Yabut, J.M.; Crane, J.D.; Green, A.E.; Keating, D.J.; Khan, W.I.; Steinberg, G.R. Emerging roles for serotonin in regulating metabolism: New implications for an ancient molecule. Endocr. Rev. 2019, 40, 1092-1107. [CrossRef]

18. Ferrero, H.; Solas, M.; Francis, P.T.; Ramirez, M.J. Serotonin 5-HT(6) receptor antagonists in Alzheimer's disease: Therapeutic rationale and current development status. CNS Drugs 2017, 31, 19-32. [CrossRef]

19. Travis, J.; Pannell, R. Selective removal of albumin from plasma by affinity chromatography. Clin. Chim. Acta 1973, 49, 49-52. [CrossRef]

20. Yang, J.; Hage, D.S. Characterization of the binding and chiral separation of D- and L-tryptophan on a high-performance immobilized human serum albumin column. J. Chromatogr. 1993, 645, 241-250. [CrossRef]

21. Sengupta, B.; Chaudhuri, S.; Banerjee, A.; Sengupta, P.K. Characterization of serotonin in protein and membrane mimetic environments: A spectroscopic study. Chem. Biodivers. 2004, 1, 868-877. [CrossRef] [PubMed]

22. Hornedo-Ortega, R.; da Costa, G.; Cerezo, A.B.; Troncoso, A.M.; Richard, T.; Garcia-Parrilla, M.C. In vitro effects of serotonin, melatonin, and other related indole compounds on amyloid- $\beta$ kinetics and neuroprotection. Mol. Nutr. Food Res. 2018, 62, 1700383. [CrossRef] [PubMed]

23. Nemashkalova, E.L.; Permyakov, E.A.; Permyakov, S.E.; Litus, E.A. Modulation of linoleic acid-binding properties of human serum albumin by divalent metal cations. Biometals 2017, 30, 341-353. [CrossRef]

24. Volkamer, A.; Kuhn, D.; Grombacher, T.; Rippmann, F.; Rarey, M. Combining global and local measures for structure-based druggability predictions. J. Chem. Inf. Modeling 2012, 52, 360-372. [CrossRef] 
25. Ghuman, J.; Zunszain, P.A.; Petitpas, I.; Bhattacharya, A.A.; Otagiri, M.; Curry, S. Structural basis of the drug-binding specificity of human serum albumin. J. Mol. Biol. 2005, 353, 38-52. [CrossRef]

26. Trott, O.; Olson, A.J. AutoDock vina: Improving the speed and accuracy of docking with a new scoring function, efficient optimization, and multithreading. J. Comput. Chem. 2010, 31, 455-461. [CrossRef]

27. Salentin, S.; Schreiber, S.; Haupt, V.J.; Adasme, M.F.; Schroeder, M. PLIP: Fully automated protein-ligand interaction profiler. Nucleic Acids Res. 2015, 43, W443-W447. [CrossRef] [PubMed]

28. Permyakov, S.E.; Ismailov, R.G.; Xue, B.; Denesyuk, A.I.; Uversky, V.N.; Permyakov, E.A. Intrinsic disorder in S100 proteins. Mol. Biosyst. 2011, 7, 2164-2180. [CrossRef] [PubMed]

29. Romero, P.; Obradovic, Z.; Li, X.; Garner, E.C.; Brown, C.J.; Dunker, A.K. Sequence complexity of disordered protein. Proteins 2001, 42, 38-48. [CrossRef]

30. Peng, K.; Radivojac, P.; Vucetic, S.; Dunker, A.K.; Obradovic, Z. Length-dependent prediction of protein intrinsic disorder. BMC Bioinform. 2006, 7, 208. [CrossRef]

31. Peng, K.; Vucetic, S.; Radivojac, P.; Brown, C.J.; Dunker, A.K.; Obradovic, Z. Optimizing long intrinsic disorder predictors with protein evolutionary information. J. Bioinform. Comput. Biol. 2005, 3, 35-60. [CrossRef] [PubMed]

32. Xue, B.; Dunbrack, R.L.; Williams, R.W.; Dunker, A.K.; Uversky, V.N. PONDR-FIT: A meta-predictor of intrinsically disordered amino acids. Biochim. Biophys. Acta 2010, 1804, 996-1010. [CrossRef]

33. Dosztányi, Z.; Csizmok, V.; Tompa, P.; Simon, I. IUPred: Web server for the prediction of intrinsically unstructured regions of proteins based on estimated energy content. Bioinformatics 2005, 21, 3433-3434. [CrossRef]

34. Dosztanyi, Z.; Csizmok, V.; Tompa, P.; Simon, I. The pairwise energy content estimated from amino acid composition discriminates between folded and intrinsically unstructured proteins. J. Mol. Biol. 2005, 347, 827-839. [CrossRef]

35. Milojevic, J.; Costa, M.; Ortiz, A.M.; Jorquera, J.I.; Melacini, G. In vitro amyloid- $\beta$ binding and inhibition of amyloid- $\beta$ selfassociation by therapeutic albumin. J. Alzheimer's Dis. 2014, 38, 753-765. [CrossRef] [PubMed]

36. Milojevic, J.; Raditsis, A.; Melacini, G. Human serum albumin inhibits Abeta fibrillization through a "monomer-competitor" mechanism. Biophys. J. 2009, 97, 2585-2594. [CrossRef] [PubMed]

37. Rózga, M.; Kłoniecki, M.; Jabłonowska, A.; Dadlez, M.; Bal, W. The binding constant for amyloid A $\beta 40$ peptide interaction with human serum albumin. Biochem. Biophys. Res. Commun. 2007, 364, 714-718. [CrossRef]

38. Costa, M.; Ortiz, A.M.; Jorquera, J.I. Therapeutic albumin binding to remove amyloid- $\beta$. J. Alzheimer's Dis. 2012, 29, 59-70. [CrossRef] [PubMed]

39. Nazarali, A.J.; Reynolds, G.P. Monoamine neurotransmitters and their metabolites in brain regions in Alzheimer's disease: A postmortem study. Cell. Mol. Neurobiol. 1992, 12, 581-587. [CrossRef]

40. Tietz, N.W.; Finley, P.R.; Pruden, E.; Amerson, A.B. Clinical Guide to Laboratory Tests, 2nd ed.; Saunders: Philadelphia, PA, USA, 1990; pp. 1-931.

41. Bunin, M.A.; Wightman, R.M. Quantitative evaluation of 5-hydroxytryptamine (serotonin) neuronal release and uptake: An investigation of extrasynaptic transmission. J. Neurosci. 1998, 18, 4854-4860. [CrossRef]

42. Cirrito, J.R.; Disabato, B.M.; Restivo, J.L.; Verges, D.K.; Goebel, W.D.; Sathyan, A.; Hayreh, D.; D’Angelo, G.; Benzinger, T.; Yoon, H.; et al. Serotonin signaling is associated with lower amyloid- $\beta$ levels and plaques in transgenic mice and humans. Proc. Natl. Acad. Sci. USA 2011, 108, 14968-14973. [CrossRef]

43. Vijayan, D.; Chandra, R. Amyloid beta hypothesis in Alzheimer's disease: Major culprits and recent therapeutic strategies. Curr. Drug Targets 2020, 21, 148-166. [CrossRef] [PubMed]

44. Catanzariti, A.-M.; Soboleva, T.A.; Jans, D.A.; Board, P.G.; Baker, R.T. An efficient system for high-level expression and easy purification of authentic recombinant proteins. Protein Sci. 2004, 13, 1331-1339. [CrossRef] [PubMed]

45. Pace, C.N.; Vajdos, F.; Fee, L.; Grimsley, G.; Gray, T. How to measure and predict the molar absorption coefficient of a protein. Protein Sci. 1995, 4, 2411-2423. [CrossRef] [PubMed]

46. Zagorski, M.G.; Yang, J.; Shao, H.; Ma, K.; Zeng, H.; Hong, A. [13] Methodological and chemical factors affecting amyloid $\beta$ peptide amyloidogenicity. In Methods in Enzymology; Academic Press: Cambridge, MA, USA, 1999; Volume 309, pp. $189-204$.

47. Berman, H.M.; Battistuz, T.; Bhat, T.N.; Bluhm, W.F.; Bourne, P.E.; Burkhardt, K.; Feng, Z.; Gilliland, G.L.; Iype, L.; Jain, S.; et al. The protein data bank. Acta Crystallographica 2002, 58, 899-907. [PubMed] 